\title{
Educational Film Experiment at Workplaces: Can Sex-Role Attitudes and Work and Life Balance Capabilities Related to Maternity Be Treated?
}

\author{
Ester Eomois \\ Estonian Business School
}

\section{Abstract}

In order to understand the impact of educational videos on the sex-role attitudes and perceptions of maternity at workplaces, an experimental research design was selected. Our survey data originates from a randomized control trial of 262 employees across Estonian organisations. After using a randomization method to select five companies from Estonian company TOP 100 ranking, an equal size control and treatment groups within these companies were randomly selected. Employees of the control group were treated with a 20-minute educational film which was designed originally for highschool students for treating a traditional male-breadwinner type of sex-role attitudes. Research goal was to explore whether an educational film as a teaching tool could be also used in organisations to affect sex role attitudes and challenges of work and life balance with focus on maternity at workplaces. Survey data collection was arranged in companies by randomly splitting the employees into treatment and control groups, and they were guided through the experiment via written instructions and HR specialist support. For data analysis, author used descriptive analysis to measure the differences between the control and treatment group by analysing employees' responses to 20 individual statements in Likert scale, with a focus on sex-role attitudes and maternity challenges questions. More specifically, author compared the differences between control and treatment group as well as the gender differences across the two groups (i.e whether an educational film had a greater affect to one over the other sex). This experiment suggests which topics in educational videos could positively affect sex-role attitudes and perceptions of maternity at workplace. The article also makes suggestions how context supporting training tools can be used together with educational videos at workplaces.

Keywords: work-life balance capabilities, maternal wall, attitudinal change, randomized control trial, traditional sex-roles

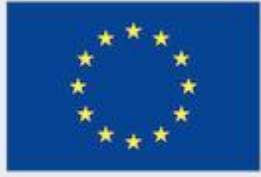

This project was funded by

the European Union's

Rights, Equality and

Citizenship Programme

(2014-2020) 


\section{Introduction}

The research brings forth that balancing work and family life is a significant challenge for women and that having small children tends to be the biggest obstacle in a woman's career. The research substantiates the fact that building a career is easier for men and the glass ceiling as well as the maternal wall has an effect on women's careers.

Work-life balance refers to the ability of every individual, regardless of gender, to coordinate work and family obligations successfully. Work, in this context, refers to paid labor performed outside the home (Wheatley, 2012).

Studies have found that, when parents manage to balance family and working life, they are more satisfied with their life, which positively impacts their mental and physical health (Haar, Russo, Suñe, \& Ollier-Malaterre, 2014).

Although half of the working-age population worldwide consists of women, men have considerably more entries to management positions and more effortless access to higher levels of organisations (Eagly et al. 1992).

Women who strive for leadership positions are often confronted with a "glass ceiling" - various invisible barriers that their male colleagues do not meet - blocking them from top management positions. The class ceiling metaphor has inspired many researchers to explore the reasons behind the phenomenon (Ryan and Haslam, 2005, 2007 and Bruckmiller and Branscombe, 2010).

As the motherhood barrier is deemed one of the most important factors hindering women's careers (Williams 2004), it is important to focus on mothers unequal distribution of child care responsibilities and discrimination at workplace, in order to improve their access to labour market and reduce the existing and potential childbirth-related and other obstacles on the career path to reach leadership positions.

There is an understanding that the quality of work and life balance depends on a combination of family member mutual agreements on sharing care, labour market and government childcare policies.

The EU Work-life Balance (WLB) Directive aims to improve families' access to family leave and flexible work arrangements. The WLB directive has entered into European Union law and must now be adopted by Member States by 2nd of August in 2022.

The Work-life Balance Directive introduces a set of legislative actions designed to modernise the existing EU legal and policy frameworks, with the aims of better supporting a work-life balance for parents and carers, encouraging a more equal sharing of parental leave between men and women, and addressing women's underrepresentation in the labour market. Measures under the directive include introduction of paternity leave; transferability option of parental leave between 
parents; introduction of carer leave; extension of flexible working arrangements for carers and working parents of children up to eight years old.

In this article, the work-life balance is conceptualised as the results of the capability to make choices between work life and family life. The paper will implement experimental design at workplaces to measure impact of educational video on the attitudes of workers of traditional and egalitarian sex roles and on perception of maternity-career at workplaces.

As underlined, our theoretical underpinnings rely on premises of the capabilities approach (Kremer 2006, Kurowska 2016, Lauri et al 2019). In general, we see that a certain mix of legal and economic constraints with conversion factor can bring along good outcomes in terms of equal capabilities of fathers and mothers to proceed with childcare and dual careers. It is also indicated by Lauri et al (2019) that certain policy mixes measuring legal and economic constraints produce different outputs (capabilities) in different institutional settings.

This research paper will focus on treating this "conversion factor" social norms i.e attitudes concerning appropriate role of mothers and fathers at work place and (in this paper called "traditional and egalitarian sex roles") and perceptions of being mother at work place (in this paper called " maternity for career fit".)

In order to understand the impact of educational videos on the sex-role attitudes and perceptions of maternity at workplaces, an experimental research design was selected. Our survey data originate from a randomized control trial (RCT) of 262 employees of Estonian organisations. After using a randomization method to select five companies from Estonian company TOP 100 ranking and then randomly selecting equal size control and treatment group within these companies. Survey data collection was arranged in companies by randomly splitting the employees into treatment and control groups.

Employees of the treatment group were treated with a 20 -minutes lasting educational film, which was designed originally for high school students for treating a traditional male-breadwinner type of sex-role attitudes.

The article will have the following structure: firstly, in-scope theoretical approaches are explained, secondly, research design and methodology is explained and thirdly, the author outlines the results and includes relevant discussion. As final part, the author will outline some practical suggestions how to make impact on traditional sex roles and maternity for career at workplaces.

\section{Theoretical framework}

There is a continued and increasing interest in sex roles (sometimes used gender roles) cultural developments and its measurements, being originally an area of focus for social psychology, now extended to education, leadership, management and 
organizational behaviour. It is interesting to note that most of the measures developed are meant to measure parental roles or related parental sex role issues (shared care, work and life balance) and not developed for young generations with no children. This is the research gap to be filled as the parental roles are developed during the later stage in adult lives, while sex roles "roll out" in other areas first.

One of the most comprehensive sex-roles measurement guides was published 30 years ago by C.A. Beere (1990) as her "Gender Roles: A Handbook of Test and Measures" was written based on extensive research including findings across 7000 journal articles in the field and over 1400+ different "measures."

One of the more recent sex roles measurement analyses and research was deliverd by John Walter 13 years ago, where in his doctoral dissertation he stated (Walter, 2018) that social developments create the need to phrase sex roles items differently than back in 1970s and 1980s where for example the childcare and careers of mothers and fathers had a different meaning years back than today.

Before starting this research, the author of this article poses a general question: can sex role attitudes be changed at all? There appears to be a "chicken and egg situation"do formal institutions make cultural (including social norms) changes happen or viceversa, do culture norms (i.e appropriate behaviours, attitudes about sex roles) drive the changes in government policies?

Sex-roles can be defined as attitudes and behaviours which are prescribed and assigned by a society to men and women on the basis of gender (Bartley, Blanton, \& Gillard, 2005:72). Diekman \& Goodfriend (2006) indicate that sex-role attitudes are prescriptive while gender roles are descriptive beliefs about gender characteristics and differences. In any terms, the author of this article understands that sex roles express how women and men should behave and the different tasks and roles they are expected to perform. And in many cases, terms sex -roles and gender roles are used interchangeably.

There are many studies which argue that formal institutional changes make informal institutional changes happen. In addition to social structural developments, the institutional context can also influence gender role attitudes, and cultural norms can have an effect on the formulation, institutionalization and efficacy of work-family policies (Budig, Misra, \& Boeckmann, 2012). Family policies likely influence gender role attitudes by signaling what is defined as appropriate behavior and by shaping the choices which are available to individuals (Jakobsson \& Kotsadam, 2010).

The author of this research believes that the effects of institutions and government policies are difficult to subtract from the effect of cultural preferences and individual attitudes towards sex roles (see Figure 1). We cannot make a difference in society by changing legal and economic constraints only, but instead should focus on "conversion factors" of gendered attitudes and social norms. It is widespread understanding that sex roles are most impacted in early age, but this research 
explores whether sex role attitudes and perception of maternity fit for career at workplaces could also be affected later in life by using educational videos.

A

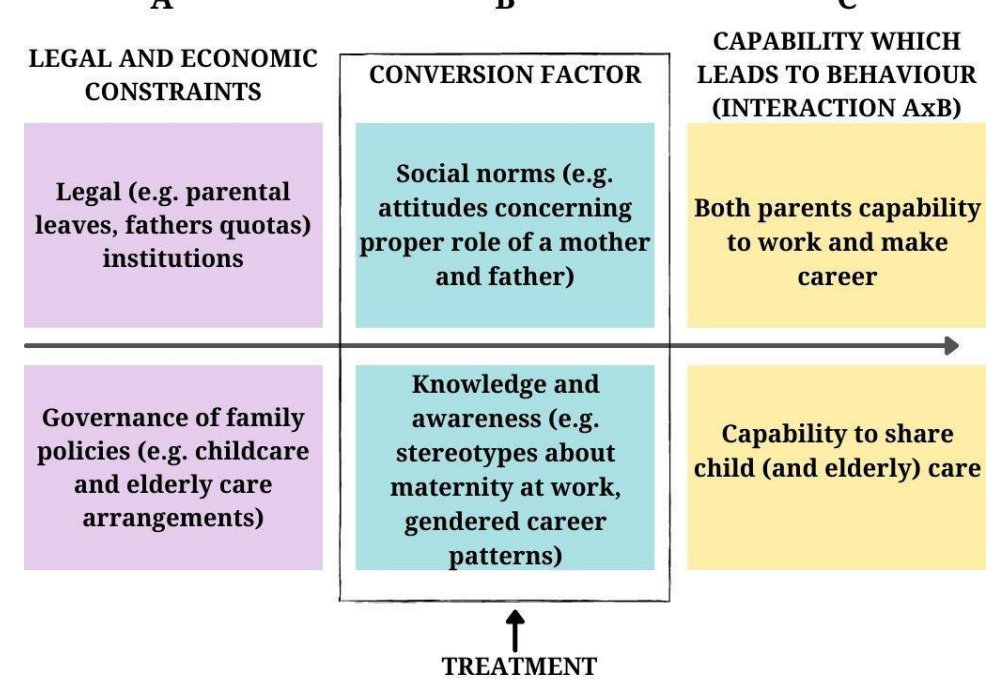

Figure 1: Theoretical model of the approach (modified from Lauri et al. 2019)

It is known that women, once becoming mothers, face many challenges. The glass ceiling phenomenon partially explains the minor proportion of young women in leadership positions. The glass ceiling theory represents an invisible barrier that blocks the advancement of women's careers more easily than men's. (Simpson \& Altman 2000). One of its major causes is that women are stereotypically ascribed feminine traits that are deemed inappropriate for a management context and thus lead to less favourable evaluations of women's performances and suitability as career promotions.

The gender (sex role) has an impact on a manager's evaluation and even high proficiency, or great success does not secure women from negative evaluation. Additionally, there's an understanding about leadership styles "fit" for female managers, which contributes to female employee's likelihood of promotion to leadership positions. (Eagly et al. 1992, 2001).

Even though the glass ceiling marks an invisible barrier on the career ladders of all women, the motherhood barrier is a part of the glass ceiling that symbolises an invisible barrier on the career ladders of women with children (Williams 2014, 16). In 2007, Shelley Correll and Stephen Benard wrote an article based on a thorough research that caused quite a stir, proving that if a woman has a child, the likelihood of her finding work decreases by $79 \%$; the likelihood of her getting a promotion is $50 \%$ lower compared to women with no children; and that the initial wage offer made to her is significantly lower, not only compared to the wage offers made to men but also 
to the wage offers made to women without children. Williams (2014) states that the women interested in building their careers have begun to knowingly evade the possibilities for the prejudice arising from the motherhood barrier.

Researchers Eagly and Karau (2002), proposed the role congruence theory, which described that even though women follow the same career tracks as men, men get promotion opportunities (Eagly \& Karau, 2002). This gender inequality that is perceived puts women in a disadvantage because they are less favorable compared to men. These findings suggest that high perceptions of gender inequality or role incongruity in the workplace make it harder for women to succeed.

There is an understanding that the quality of work and life balance depend on a combination of parents balancing the professional and family lives, labour market and government childcare policies.

In the studies conducted so far, three separate problems are differentiated for the motherhood barrier: the parental leave and competence, children and career - the efficiency of work, and the balance of work and family life.

Several studies (Correll \& Benard 2005, Correll \& Shelley 2007) have proved that for the employer, motherhood determines, by default, a lower level of competence, desire to dedicate to work, and thus the work-related capability of a woman (Correll \& Ridgeway 2003, 29). The difference between perceiving the competence of a "mother" and a classic "good employee" is even bigger than the difference between perceiving the comparable competencies of a woman and a man, as the cultural stereotype of a "good mother" is even more different from the cultural stereotype of a "good employee" - she is significantly less competent. Based on the lower competence, it is assumed that a woman with children will contribute less and make less effort, thus being less efficient (Correll \& Ridgeway 2004, 684-686).

To prove their competence, mothers have to work significantly harder than others do in their professional lives, constantly demonstrating the completion of duties above their abilities. Each throwback is seen as a direct consequence of the employee's motherhood and the resulting low efficiency of work, which makes the career efforts of women with children very complicated (Correll \& Bernard 2005, 1302).

Glass describes (2004) that even though modern employers have increasingly begun to offer their employees opportunities for flexible working time, studies show that taking advantage of the opportunity for the flexible organisation of working time is often also perceived as punishment in a way. If mothers take advantage of the opportunities for flexible working time, their colleagues will begin to increasingly associate them with the traits and stereotypes of a parent, which is immediately accompanied by the above-mentioned prejudices regarding competence and lower efficiency. As a result, a woman with children using the option of flexible working time will actually have to work more than by simply sitting in an office for a regulated working time (Glass 2004, 372-375). 


\section{Methodology}

Sampling and data collection. The research survey data originate from a randomized control trial (RCT) of 262 employees across five randomly selected Estonian organisations. The five organisations were selected after using a computerized randomisation method, a random allocation of Excel list of top 100 Estonian companies. This list of 100 Estonian companies is created every year by the leading Estonian daily newspaper „Äripäev.” It is developed based on growth indicators in 2019/ 2018 as of sales revenue, operating profit, and return on investment. In order to qualify, companies need to have been active in 2020 and have a minimum annual sales revenue of 18.8 million euros.

All randomly selected companies were contacted by the researcher. One company declined due to Covid -19 challenging times and a new company was selected by computerized randomisation method. With help of HR directors in selected five organizations, equal size control and treatment group within these companies were randomly selected and instructed respectively.

Research was carried out during the months of May to June in 2021. Due to Covid-19 restrictions, online channels (Zoom, Microsoft Teams, companies' internal conference channels) were used to provide instructions and experiment tools (educational video). Survey instrument itself was available online as the preferred method for companies and respondents. For one of the organisations (production company), a group viewing for educational film was organised in a factory conference room and surveys were filled in individually in paper as respondents had no access to online channels.

Demographic characteristics. Table 1 and 2 display demographic characteristics of our study. In general, the employees were divided in three different age groups: 20 $30,31-40$, and 41+ years old. Across all respondents, 50 employees were between 2030 year old, 81 were 31-40 year old, and the highest number of employees, 131 , were over 41 years old. Out of all respondents, 75 were male $(0=$ male), and 187 were female (1=female) (see table 2). Furthermore, in our data set we had some background characteristics that were categorical and ordered in the following way indicating one's level of education acquired: $1=$ Master's Degree, $2=$ Bachelor's Degree, 3= High School Degree, 4= Vocational Education, 5= Unfinished Higher Education, 6= Basic Education. As table 2 shows, most respondents are highly educated, with $63 \%$ of respondents having at least a bachelor's degree or above.

As tables 3-6 show, while there are some differences in age distribution across the control and treatment group, there are no statistically significant differences across demographic and background characteristics of the control and treatment group, which indicates that our randomization method was successful.

Table 1: Age distribution of employees 
150

100

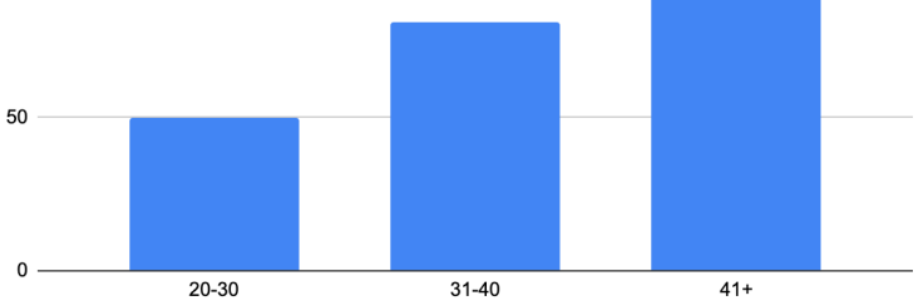

Table 2: Other demographic characteristics of employees

\begin{tabular}{lllll|l|l|l}
\hline $\begin{array}{l}\text { Statisti } \\
\mathrm{c}\end{array}$ & $\mathrm{N}$ & Mean & $\begin{array}{l}\text { St.D } \\
\text { ev }\end{array}$ & Min & $\begin{array}{l}\text { Pctl } \\
(25)\end{array}$ & $\begin{array}{l}\text { Pctl } \\
(75)\end{array}$ & Max \\
\hline $\begin{array}{l}\text { Gende } \\
\mathrm{r}\end{array}$ & 2 & 0.714 & 0.45 & 0 & 0 & 1 & 1 \\
& 6 & & 3 & & & & \\
$\begin{array}{l}\text { Educat } \\
\text { ionLev } \\
\text { el }\end{array}$ & 2 & 2.508 & 1.40 & 1 & 1 & 3 & 6 \\
\hline
\end{tabular}

Table 3: Age distribution of control group

Age Distribution of Control Group

80

60

40

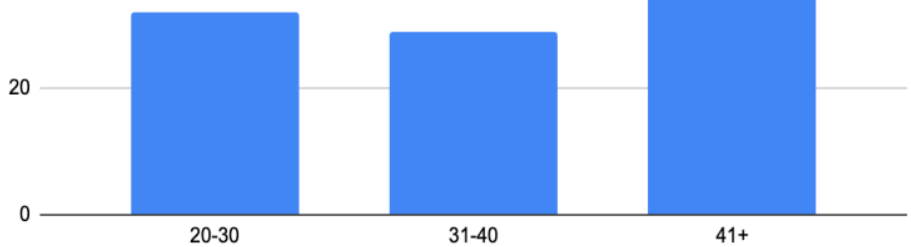


Table 4: Other demographic characteristics of control group

\begin{tabular}{lllll|l|l|l}
\hline $\begin{array}{l}\text { Statisti } \\
\mathrm{C}\end{array}$ & $\mathrm{N}$ & Mean & $\begin{array}{l}\text { St.D } \\
\mathrm{ev}\end{array}$ & Min & $\begin{array}{l}\text { Pctl } \\
(25)\end{array}$ & $\begin{array}{l}\text { Pctl } \\
(75)\end{array}$ & Max \\
\hline Gender & 2 & 0.695 & $\begin{array}{l}0.46 \\
2\end{array}$ & 0 & 0 & 1 & 1 \\
& 2 & & 2 & & & & \\
Educati & 2 & 2.718 & 1.52 & 1 & 2 & 4 & 6 \\
onLeve & 6 & & 6 & & & & \\
I & 2 & & & & & & \\
\hline
\end{tabular}

Table 5: Age distribution of treatment group

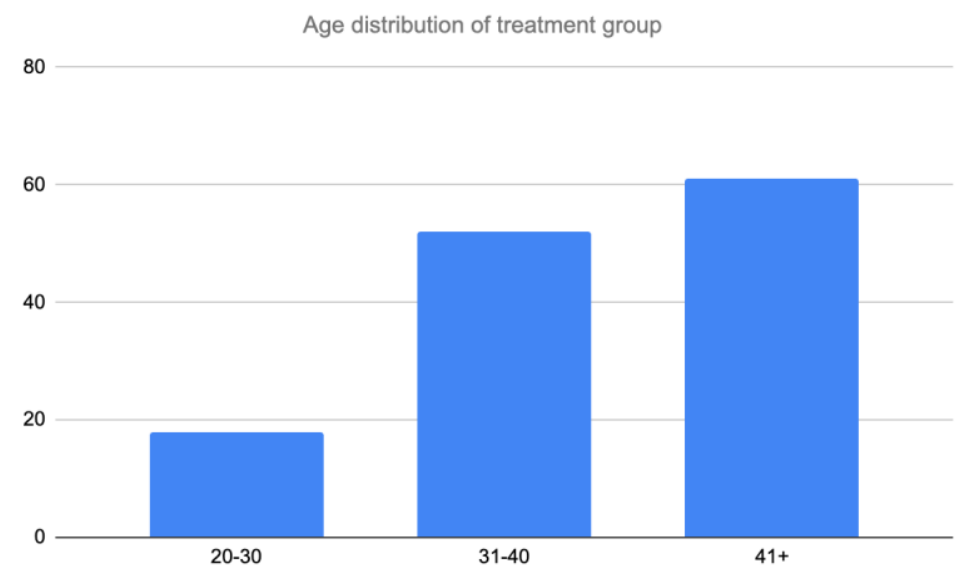

Table 6: Other demographic characteristics of treatment group

\begin{tabular}{lllll|l|l|l}
\hline $\begin{array}{l}\text { Statisti } \\
\mathrm{c}\end{array}$ & $\mathrm{N}$ & Mean & $\begin{array}{l}\text { St.D } \\
\mathrm{ev}\end{array}$ & Min & $\begin{array}{l}\text { Pctl } \\
(25)\end{array}$ & $\begin{array}{l}\text { Pctl } \\
(75)\end{array}$ & Max \\
\hline Gender & 2 & 0.733 & 0.44 & 0 & 0 & 1 & 1 \\
& 6 & & 4 & & & & \\
& 2 & & & & & & \\
& 2 & 2.298 & 1.23 & 1 & 1 & 3 & 6 \\
$\begin{array}{l}\text { Educati } \\
\text { onLeve }\end{array}$ & 6 & & 8 & & & & \\
I & 2 & & & & & & \\
\hline
\end{tabular}

Methodology. For this research, the author was to measure the differences between the control and treatment group by analysing employees' responses to 20 individual statements on a Likert scale, with a focus on sex-role attitudes and maternity/ career 
challenges questions. More specifically, the author's goal was to find out whether an education film has impact on:

The general differences between control and treatment group

The gender differences across the two groups (i.e. whether an educational film had a greater effect to one over the other gender).

Analyses methods. For data analysis, the author has used descriptive analysis, such as minimums, maximums, means and standard deviations to analyze data points from a 6 point Likert scale, which is one of the most broadly used methods for scaling responses in survey studies. The author has also included percentile calculations to understand how respondents' perceptions spread across the spectrum.

3 The design of the treatment and survey instrument

Before filling out the survey, employees in the treatment group were shown a 20minute-long educational film, produced by Kuukulgur Company, Estonia, and delivered by well-known Estonian actors. For script writing, the author of the article was one of the members of the research group to provide background research about challenges in the area of parental challenges of WLB.

The educational film consists of 8 short sketches of a family of full-time working mother (data analytics specialist), full- time working father (works for logistics as specialist), and how they balance their work and life as parents of two children (toddler and a schoolgirl) while also taking care of the sick grandfather. More specifically, sketches include the usual situations of working parents, addressing the following topics:

Challenges on work and life balance due to long working hours and no options for flexible working hours. Effect on both parents, but more on mothers.

Challenges on taking care of the elderly members at home. Possibilities for asking help.

Pressure on working mothers to be perfect at work as well taking care of the family as the main care provider.

Discrimination at work, questions about family status (about number of children) at job interview and limited possibility to plan flexible working hours as a working mother.

Children at workplace meetings, options for public childcare.

Shared care responsibilities between mother and father, mother's responsibility to take care of family while working full time, mother's "free time" is taking care of family.

Right to get paid leave for childcare and ask for help from the municipal government for elderly care. 
The educational video has a "happy ending" as the family furthers themselves, makes arrangements in their life (better shared care of children), the elderly family member has a role in daily home chores, mother's employer understands that having family does not make mother a less efficient employee, and flexible working hours and place does not inhibit work results.

To strengthen the effect of the educational video, the treatment also includes a guiding question after every scetch (such as " Do you think that children benefit when both parents share care equally" etc.) to make a higher cognitive affect towards more egalitarian sex-roles and maternity perceptions at work place.

These educational video series were originally produced as educational tool for highschool children (15 years+) to be used in the classrooms, to make impact on their attitudes of sex-roles development and provide tools how to balance work and life in the future. In schools, educational videos are accompanied by teacher lectures and case study analyses.

The survey instrument. The author used a 6-point Likert scale, which is one of the most common methods to measure a wide range of perceptions, motivations, and intentions. To ensure that the overall likert scale can be treated interval level, an evenly spaced standardized response categories were utilized: 1-totally disagree, 2 disagree; 3-slightly disagree; 4-slightly agree; 5 -agree; 6 - totally agree.

The survey instrument consisted of two parts including a total of 20 statements. First part consisted of 10 statements related to traditional and more egalitarian sex roles (Adapted from Walter doctoral dissertation 2018), and the second part consisted of 10 statements related to maternity fit to career (statements were composed by the author based on relevant research concepts in that area).

Survey part 1. Statements to assess employees'attitudes towards traditional and more egalitarian sex roles. Walter (2018) divides the new structure of sex roles, as he has stated that sex roles measurement in $21^{\text {st }}$ century needs to be approached differently as the meaning of parenting, family care and work and life balance are continuously changing. His research states that there are two latent variables: traditional sex roles (originally traditional male- breadwinner concept) and modern sex roles (known also as an egalitarian caregiver concept).

FULMW A full-time working mother can normally establish just as close a relationship with her small child as a mother who doesn't work. (egalitarian caregiver)

BOTHFUL The best way to organize family and work life is for both partners to work full-time and to look after the home and children equally. (egalitarian caregiver)

CHLSUF A small child is bound to suffer if his or her mother goes out to work. (reverse scale) (male breadwinner) 
MBREAD It is much better for everyone concerned if the man goes out to work and the woman stays at home and looks after the house and children. (later used in survey in reverse scale)(male breadwinner)

CHLBEN A child actually benefits if his or her mother has a job rather than just concentrating on the home. (egalitarian caregiver)

BOTHPART The best way to organize family and work life is for both partners to work part-time and to look after the home and children equally. (reverse scale) (male breadwinner)

FULDBAD A father who works full-time cannot care for his children properly. (reverse scale) (male breadwinner)

WRKMHOME Even if both parents work full-time, it is still better if the mother has main responsibility for looking after the home and children. (reverse scale) (male breadwinner)

FULDW A full-time working father can normally establish just as close a relationship with his small child as a father who doesn't work. (egalitarian caregiver)

ROLECHA A man can be responsible for looking after the home and children just as well while the woman works full-time. (egalitarian caregiver)

Survey part 2. Statements to assess employees 'attitudes towards maternity fit for career were constructed by the author of the article and based on research literature on "maternal wall," "glass ceiling theories" and "gendered career paths" due to the author's work in doctoral dissertation.

WLB1 A woman has to cope perfectly with both her mother role and the role as the best employee, at the same time. (role congruity theory)

WLB2 It is easier for men to pursue a career than women. (gendered career paths)

WLB3 The presence of children affects women's careers more than men's. (gendered career paths)

WLB4 A woman who is pregnant or has small children is not in a position of responsibility because she cannot be fully committed to work. (maternal wall)

WLB5 A woman who is pregnant or has small children is less effective at work as she prioritizes children over work. (maternal wall)

WLB6 A woman who is pregnant or has small children is less competent at work. (perceived loss of professional competence while being a mother)

WLB7 Companies prefer men in leadership positions. (gendered career paths)

WLB8 Organising work and life balance is the mother's responsibility. (work and life balance challenges) 
WLB9 Finding work and life balance is mostly a problem for women. (work and life balance challenges)

WLB10 Taking children to work reduces work efficiency. (work and life balance challenges)

Please note that this survey instrument consists of additional 10 statements related to institutional practices to regulate work and life balance, Covid-19 impact on parental roles and care. These statements were not analysed and presented in this article due to the scope of this study.

\section{Results and Discussion}

The author of the article compares the differences between control and treatment group as well as the gender differences across the two groups (i.e whether an educational film had a greater affect to one over the other sex).

The author presents the results and discussion in two parts:

1) Sex role attitudes

2) Attitudes to maternity fit for career and WLB challenges

In both parts, the general differences between control and treatment group as well as the gender differences across the two groups results are presented.

Results and discussion on sex-role attitudes: On average, employees in the treatment group were slightly more favourable towards modern sex roles when compared to employees in the control group (see tables 7-12).

Table 7. Descriptives of the Sex-Role Attitudes: Control Group

\begin{tabular}{lllll|l|l|l|}
\hline Statistic & $\mathrm{N}$ & Mean & St.Dev & Min & Pctl (25) & Pctl (75) & Max \\
\hline FULMW & 131 & 4.443 & 1.484 & 1 & 3 & 6 & 6 \\
BOTHFUL & 131 & 4.947 & 1.159 & 2 & 4 & 6 & 6 \\
\hline CHLSUF & 131 & 3.603 & 1.597 & 1 & 2 & 5 & 6 \\
\hline MBREAD & 131 & 2.519 & 1.454 & 1 & 1 & 4 & 6 \\
\hline CHLBEN & 131 & 4.489 & 1.321 & 1 & 4 & 6 & 6 \\
\hline BOTHPART & 131 & 4.344 & 1.518 & 1 & 3 & 6 & 6 \\
\hline FULDBAD & 131 & 2.122 & 1.436 & 1 & 1 & 3 & 6 \\
\hline WRKMHOM & 131 & 2.153 & 1.406 & 1 & 1 & 3 & 6 \\
\hline E & 131 & & & 1 & 6 \\
\hline
\end{tabular}




\begin{tabular}{|lrrrrrrr|}
\hline FULDW & 131 & 4.237 & 1.493 & 1 & 3 & 6 & 6 \\
\hline ROLECHA & 131 & 5.084 & 1.151 & 1 & 4.5 & 6 & 6 \\
\hline
\end{tabular}

Table 8. Descriptives of the Sex-Role Attitudes: Control Group (Male)

\begin{tabular}{|c|c|c|c|c|c|c|c|}
\hline Statistic & N & Mean & St.Dev & Min & Pctl (25) & Pctl (75) & Max \\
\hline FULMW & 40 & 4.100 & 1.464 & 1 & 3 & 5 & 6 \\
\hline BOTHFUL & 40 & 4.750 & 1.149 & 1 & 4 & 6 & 6 \\
\hline CHLSUF & 40 & 3.525 & 1.450 & 1 & 2 & 4.25 & 6 \\
\hline MBREAD & 40 & 2.800 & 1.436 & 1 & 2 & 4 & 5 \\
\hline CHLBEN & 40 & 4.250 & 1.171 & 1 & 3.75 & 5 & 6 \\
\hline BOTHPART & 40 & 3.975 & 1.476 & 1 & 3 & 5 & 6 \\
\hline FULDBAD & 40 & 2.275 & 1.485 & 1 & 1 & 3 & 6 \\
\hline $\begin{array}{l}\text { WRKMHOM } \\
\text { E }\end{array}$ & 40 & 2.375 & 1.390 & 1 & 1 & 3 & 6 \\
\hline FULDW & 40 & 3.950 & 1.319 & 1 & 3 & 5 & 6 \\
\hline ROLECHA & 40 & 4.875 & 1.305 & 1 & 4 & 6 & 6 \\
\hline
\end{tabular}

Table 9. Descriptives of the Sex-Role Attitudes: Control Group (Female)

\begin{tabular}{lllll|l|l|l}
\hline Statistic & N & Mean & St.Dev & Min & Pctl (25) & Pctl (75) & Max \\
\hline FULMW & 91 & 4.593 & 1.476 & 1 & 3 & 5 & 6 \\
BOTHFUL & 91 & 5.033 & 1.159 & 1 & 4 & 6 & 6 \\
\hline CHLSUF & 91 & 3.637 & 1.663 & 1 & 2 & 4.25 & 6 \\
\hline MBREAD & 91 & 2.396 & 1.452 & 1 & 2 & 4 & 5 \\
\hline CHLBEN & 91 & 4.593 & 1.374 & 1 & 3.75 & 5 & 6 \\
\hline BOTHPART & 91 & 4.505 & 1.516 & 1 & 3 & 5 & 6 \\
\hline FULDBAD & 91 & 2.055 & 1.417 & 1 & 1 & 3 & 6 \\
\hline
\end{tabular}




$\begin{array}{llllllll}\text { WRKMHOM } & 91 & 2.055 & 1.409 & 1 & 1 & 3 & 6\end{array}$

\begin{tabular}{|c|c|c|c|c|c|c|c|}
\hline FULDW & 91 & 4.363 & 1.553 & 1 & 3 & 5 & 6 \\
\hline ROLECHA & 91 & 5.176 & 1.071 & 1 & 4 & 6 & 6 \\
\hline
\end{tabular}

Table 10. Descriptives of the Sex-Role Attitudes: Treatment Group

\begin{tabular}{|c|c|c|c|c|c|c|c|}
\hline Statistic & $\mathrm{N}$ & Mean & St.Dev & Min & Pctl (25) & Pctl (75) & Max \\
\hline FULMW & 131 & 4.702 & 1.275 & 1 & 4 & 6 & 6 \\
\hline BOTHFUL & 131 & 5.260 & 0.973 & 1 & 5 & 6 & 6 \\
\hline CHLSUF & 131 & 3.336 & 1.634 & 1 & 2 & 4 & 6 \\
\hline MBREAD & 131 & 1.931 & 1.083 & 1 & 1 & 2.5 & 6 \\
\hline CHLBEN & 131 & 4.763 & 1.288 & 1 & 4 & 6 & 6 \\
\hline BOTHPART & 131 & 4.321 & 1.515 & 1 & 3 & 6 & 6 \\
\hline FULDBAD & 131 & 1.939 & 1.357 & 1 & 1 & 2 & 6 \\
\hline $\begin{array}{l}\text { WRKMHOM } \\
\text { E }\end{array}$ & 131 & 1.626 & 0.979 & 1 & 1 & 2 & 5 \\
\hline FULDW & 131 & 4.534 & 1.459 & 1 & 3.5 & 6 & 6 \\
\hline ROLECHA & 131 & 5.382 & 0.932 & 2 & 5 & 6 & 6 \\
\hline
\end{tabular}

Table 11. Descriptives of the Sex-Role Attitudes: Treatment Group (Male)

\begin{tabular}{lcccc|c|c|l|}
\hline Statistic & N & Mean & St.Dev & Min & Pctl (25) & Pctl (75) & Max \\
\hline FULMW & 35 & 4.286 & 1.619 & 1 & 3 & 6 & 6 \\
BOTHFUL & 35 & 5.114 & 1.255 & 1 & 5 & 6 & 6 \\
\hline CHLSUF & 35 & 3.457 & 1.853 & 1 & 2 & 5 & 6 \\
\hline MBREAD & 35 & 1.857 & 1.033 & 1 & 1 & 2 & 4 \\
\hline CHLBEN & 35 & 4.629 & 1.477 & 1 & 4 & 6 & 6 \\
\hline BOTHPART & 35 & 4.257 & 1.669 & 1 & 3 & 6 & 6 \\
\hline
\end{tabular}




\begin{tabular}{lllll|l|l|l|l|}
\hline FULDBAD & 35 & 1.771 & 1.416 & 1 & 1 & 2 & 6 \\
\hline $\begin{array}{l}\text { WRKMHOM } \\
\text { E }\end{array}$ & 35 & 1.571 & 0.948 & 1 & 1 & 2 & 4 \\
\hline FULDW & 35 & 4.171 & 1.855 & 1 & 2.5 & 6 & 6 \\
\hline ROLECHA & 35 & 5.200 & 1.052 & 2 & 5 & 6 & 6 \\
\hline
\end{tabular}

Table 12. Descriptives of the Sex-Role Attitudes: Treatment Group (Female)

\begin{tabular}{|c|c|c|c|c|c|c|c|}
\hline Statistic & $\mathrm{N}$ & Mean & St.Dev & Min & Pctl (25) & Pctl (75) & Max \\
\hline FULMW & 96 & 4.854 & 1.095 & 2 & 4 & 6 & 6 \\
\hline BOTHFUL & 96 & 5.313 & 0.850 & 3 & 5 & 6 & 6 \\
\hline CHLSUF & 96 & 3.292 & 1.555 & 1 & 2 & 4 & 6 \\
\hline MBREAD & 96 & 1.958 & 1.104 & 1 & 1 & 3 & 4 \\
\hline CHLBEN & 96 & 4.813 & 1.217 & 1 & 4 & 6 & 6 \\
\hline BOTHPART & 96 & 4.344 & 1.464 & 1 & 3 & 6 & 6 \\
\hline FULDBAD & 96 & 2.000 & 1.338 & 1 & 1 & 3 & 6 \\
\hline $\begin{array}{l}\text { WRKMHOM } \\
\text { E }\end{array}$ & 96 & 1.646 & 0.995 & 1 & 1 & 2 & 6 \\
\hline FULDW & 96 & 4.667 & 1.270 & 1 & 4 & 6 & 6 \\
\hline ROLECHA & 96 & 5.448 & 0.881 & 2 & 5 & 6 & 6 \\
\hline
\end{tabular}

On average, statements, which the educational film seemed to have the most (positive) impact on, were the most fundamental statements around traditional (breadwinner) sex roles:

(MBREAD) It is much better for everyone concerned if the man goes out to work and the woman stays at home and looks after the house and children. (later used in survey in reverse scale) (male breadwinner)

(WRKMHOME) Even if both parents work full-time, it is still better if the mother has the main responsibility for looking after the home and children. (reverse scale) (male breadwinner)

While comparing responses to statements related to traditional sex-role attitudes across male and female respondents, the more significant change between the 
treatment and control group was driven by the changes in men's perceptions, suggesting that the educational videos may have more impact on men's perceptions compared to that of women's when it comes to modernising traditional (male breadwinner) sex role attitudes.

Results on maternity career fit. The differences between the treatment and control group results were less notable in responses to maternity fit for career statements compared to those of traditional sex-role attitudes (see tables 13-18).

Table 13. Descriptives of the Maternity Career Fit (WLB) Attitudes: Control Group

\begin{tabular}{|lrrrr|r|r|l|}
\hline Statistic & N & Mean & St.Dev & Min & Pctl (25) & Pctl (75) & Max \\
\hline WLB1 & 131 & 3.153 & 1.778 & 1 & 2 & 5 & 6 \\
WLB2 & 131 & 4.084 & 1.504 & 1 & 3 & 5 & 6 \\
\hline WLB3 & 131 & 4.496 & 1.361 & 1 & 4 & 6 & 6 \\
\hline WLB4 & 131 & 2.328 & 1.372 & 1 & 1 & 3 & 5 \\
\hline WLB5 & 131 & 2.481 & 1.332 & 1 & 1 & 3 & 6 \\
\hline WLB6 & 131 & 1.595 & 1.051 & 1 & 1 & 2 & 6 \\
\hline WLB7 & 131 & 3.954 & 1.397 & 1 & 3 & 5 & 6 \\
\hline WLB8 & 131 & 2.916 & 1.669 & 1 & 1 & 4 & 6 \\
\hline WLB9 & 131 & 3.290 & 1.605 & 1 & 2 & 5 & 6 \\
\hline WLB10 & 131 & 3.763 & 1.538 & 1 & 3 & 5 & 6 \\
\hline
\end{tabular}

Table 14. Descriptives of the Maternity Career Fit (WLB) Attitudes: Control Group (Male only)

\begin{tabular}{lllll|l|l|l}
\hline Statistic & N & Mean & St.Dev & Min & Pctl (25) & Pctl (75) & Max \\
\hline WLB1 & 40 & 2.825 & 1.448 & 1 & 2 & 4 & 6 \\
WLB2 & 40 & 3.500 & 1.414 & 1 & 2 & 5 & 6 \\
\hline WLB3 & 40 & 3.775 & 1.561 & 1 & 2.75 & 5 & 6 \\
\hline WLB4 & 40 & 2.675 & 1.474 & 1 & 1.75 & 4 & 5 \\
\hline WLB5 & 40 & 2.925 & 1.509 & 1 & 2 & 4 & 6 \\
\hline
\end{tabular}




\begin{tabular}{|lrrrr|r|r|r|r|}
\hline WLB6 & 40 & 1.900 & 1.236 & 1 & 1 & 2 & 6 \\
\hline WLB7 & 40 & 3.450 & 1.260 & 1 & 3 & 4 & 6 \\
\hline WLB8 & 40 & 2.325 & 1.509 & 1 & 1 & 3 & 6 \\
\hline WLB9 & 40 & 2.450 & 1.176 & 1 & 1 & 3 & 6 \\
\hline WLB10 & 40 & 4.050 & 1.413 & 1 & 3 & 5 & 6 \\
\hline
\end{tabular}

Table 15. Descriptives of the Maternity Career Fit (WLB) Attitudes: Control Group (Female only)

\begin{tabular}{|lllll|l|l|l|}
\hline Statistic & $\mathrm{N}$ & Mean & St.Dev & Min & Pctl (25) & Pctl (75) & Max \\
\hline WLB1 & 91 & 3.297 & 1.894 & 1 & 1 & 5 & 6 \\
WLB2 & 91 & 4.341 & 1.477 & 1 & 4 & 5 & 6 \\
\hline WLB3 & 91 & 4.813 & 1.134 & 1 & 4 & 6 & 6 \\
\hline WLB4 & 91 & 2.176 & 1.305 & 1 & 1 & 3 & 5 \\
\hline WLB5 & 91 & 2.286 & 1.204 & 1 & 1 & 3 & 6 \\
\hline WLB6 & 91 & 1.462 & 0.935 & 1 & 1 & 2 & 6 \\
\hline WLB7 & 91 & 4.176 & 1.403 & 1 & 3 & 5 & 6 \\
\hline WLB8 & 91 & 3.176 & 1.677 & 1 & 1 & 4 & 6 \\
\hline WLB9 & 91 & 3.659 & 1.634 & 1 & 3 & 5 & 6 \\
\hline WLB10 & 91 & 3.637 & 1.581 & 1 & 3 & 5 & 6 \\
\hline
\end{tabular}

Table 16. Descriptives of the Maternity Career Fit (WLB) Attitudes: Treatment Group

\begin{tabular}{lllllll|l|l}
\hline Statistic & N & Mean & St.Dev & Min & Pctl (25) & Pctl (75) & Max \\
\hline WLB1 & 131 & 2.695 & 1.441 & 1 & 1.5 & 4 & 6 \\
WLB2 & 131 & 4.153 & 1.501 & 1 & 3.5 & 5 & 6 \\
\hline WLB3 & 131 & 4.351 & 1.392 & 1 & 4 & 5 & 6 \\
\hline WLB4 & 131 & 1.901 & 1.059 & 1 & 1 & 2 & 5 \\
\hline
\end{tabular}




\begin{tabular}{|lrrrr|r|r|r|r|}
\hline WLB5 & 131 & 2.153 & 1.180 & 1 & 1 & 3 & 5 \\
\hline WLB6 & 131 & 1.160 & 0.461 & 1 & 1 & 1 & 4 \\
\hline WLB7 & 131 & 4.053 & 1.377 & 1 & 4 & 5 & 6 \\
\hline WLB8 & 131 & 2.527 & 1.679 & 1 & 1 & 4 & 6 \\
\hline WLB9 & 131 & 3.473 & 1.720 & 1 & 2 & 5 & 6 \\
\hline WLB10 & 131 & 3.237 & 1.488 & 1 & 2 & 5 & 6 \\
\hline
\end{tabular}

Table 17. Descriptives of the Maternity Career Fit (WLB) Attitudes: Treatment Group (Male only)

\begin{tabular}{|lllll|l|l|l|}
\hline Statistic & N & Mean & St.Dev & Min & Pctl (25) & Pctl (75) & Max \\
\hline WLB1 & 35 & 2.457 & 1.268 & 1 & 1 & 3.5 & 5 \\
WLB2 & 35 & 3.143 & 1.574 & 1 & 2 & 5 & 6 \\
\hline WLB3 & 35 & 3.829 & 1.599 & 1 & 3 & 5 & 6 \\
\hline WLB4 & 35 & 1.971 & 1.200 & 1 & 1 & 2 & 5 \\
\hline WLB5 & 35 & 2.400 & 1.333 & 1 & 1 & 3.5 & 5 \\
\hline WLB6 & 35 & 1.143 & 0.550 & 1 & 1 & 1 & 4 \\
\hline WLB7 & 35 & 3.000 & 1.572 & 1 & 1 & 4 & 6 \\
\hline WLB8 & 35 & 1.657 & 1.027 & 1 & 1 & 2 & 4 \\
\hline WLB9 & 35 & 2.114 & 1.568 & 1 & 1 & 3 & 6 \\
\hline WLB10 & 35 & 3.686 & 1.641 & 1 & 2 & 5 & 6 \\
\hline
\end{tabular}

Table 18. Descriptives of the Maternity Career Fit (WLB) Attitudes: Treatment Group (Female only)

\begin{tabular}{lllll|l|l|l|}
\hline Statistic & $\mathrm{N}$ & Mean & St.Dev & Min & Pctl (25) & Pctl (75) & Max \\
\hline WLB1 & 96 & 2.781 & 1.495 & 1 & 2 & 4 & 6 \\
WLB2 & 96 & 4.521 & 1.298 & 1 & 4 & 5 & 6 \\
\hline WLB3 & 96 & 4.542 & 1.264 & 1 & 4 & 5 & 6 \\
\hline
\end{tabular}




\begin{tabular}{|lrrrr|r|r|r|r|}
\hline WLB4 & 96 & 1.875 & 1.008 & 1 & 1 & 2 & 5 \\
\hline WLB5 & 96 & 2.063 & 1.113 & 1 & 1 & 3 & 5 \\
\hline WLB6 & 96 & 1.167 & 0.427 & 1 & 1 & 1 & 3 \\
\hline WLB7 & 96 & 4.438 & 1.074 & 1 & 4 & 5 & 6 \\
\hline WLB8 & 96 & 2.844 & 1.761 & 1 & 1 & 4.25 & 6 \\
\hline WLB9 & 96 & 3.969 & 1.497 & 1 & 3 & 5 & 6 \\
\hline WLB10 & 96 & 3.073 & 1.401 & 1 & 2 & 4 & 6 \\
\hline
\end{tabular}

The statements regarding maternity in which the educational film had the bigger impact on (see tables 13-18) were as follows:

(WLB1) A woman has to cope perfectly with both her mother role and the role as the best employee, at the same time. (role congruity theory)

(WLB4)A woman who is pregnant or has small children is not in a position of responsibility because she cannot be fully committed to work. (maternal wall)

(WLB6) A woman who is pregnant or has small children is less competent at work. (perceived loss of professional competence while being a mother)

While comparing responses to maternity related statements across genders (see tables 14-15 and 17-18), interestingly, educational video had larger impact on men for statements that were rooted from the traditional sex role of the mother/ caregiver:

(WLB4) A woman who is pregnant or has small children is not in a position of responsibility because she cannot be fully committed to work. (maternal wall)

(WLB6) A woman who is pregnant or has small children is less competent at work. (perceived loss of professional competence while being a mother)

(WLB8) Organising work and life balance is the mother's responsibility. (work and life balance challenges)

However, for statements that were driven from challenges in work and life balance, an educational video had larger effect on women:

(WLB1) A woman has to cope perfectly with both her mother role and the role as the best employee, at the same time. (role congruity theory)

(WLB10)Taking children to work reduces work efficiency. (work and life balance challenges) 
Interestingly, there were also statements where the educational video had minimal to no impact at all (i.e. same results in the treatment and control group), insinuating the existence of common and deeply rooted beliefs across genders:

(WLB 2) It is easier for men to pursue a career than women.

(WLB 3) The presence of children affects women's careers more than men's.

This analysis suggests that the educational video can serve a different purpose based on gender. While for men it is mainly about awareness- that is, changing their deeply rooted pre-existing attitudes about traditional sex roles, for women it is more about encouragement towards embodying modern sex roles.

For women, it is most important to provide them confidence and show different ways to make it work. For men, it is important to challenge their pre-existing perceptions of traditional sex roles through open communication and awareness-based content. Finding that there were some statements that were not affected by the educational video (i.e. some deeply rooted attitudes), further supports the importance of connecting the right content with the right channels. Therefore, it is essential to understand the areas that can be influenced through the educational video, and as a result tailor the content accordingly.

\section{Conclusions}

This article discusses whether sex-role attitudes can be changed only evolutionary (i.e. over time naturally) or they can be treated by educational videos? The theoretical remises lie to the founding of capabilities building approach (Kurowska 2016, Laur et al. 2019), which explains the success of the family policies in supporting the work-life balance by prevailing attitudes about the "proper" sex-roles in the society. For various outcomes of work-life balance (e.g. gender wage gap, caregiving time gap) family policies interact with attitudinal factors.

This article highlights the importance of three areas when it comes to changing sex role attitudes in the workplace: it is about content of educational videos, channel of delivery, and audience.

This analysis of this article informs us about the "content" area, more specifically outlining topics that can be most effective when using educational videos to positively affect sex-role attitudes and perceptions of work and life balance capabilities with focus on maternity. Furthermore, it not only highlights the importance of content itself, but also the significance of tailoring the content to the right target audience (women vs. men). It serves as a good groundwork for future analysis to further gain insights on how to change perceptions of sex-role attitudes and work and life capabilities in the workplace.

To achieve the objectives of this specific research analysis, the educational video was shown in isolation without any other educational tools (lecture, case study analyses, discussion on topics), and in many areas we can see small changes in sex role 
attitudes. Surprisingly, the research results show that men are more subject to change their views on originally very traditional attitudes on sex roles.

It is clear that educational video (or series of videos with regular repetition) is an impactful educational tool, as research in many ways discusses the so-called "multimedia principle". Providing words with pictures, images, or other graphics enhances learning relative to materials that include only words or, as in most work places, sex roles and family challenges are not talked at all openly and in meaningful ways.

The author of the article will outline the following recommendations how the impact of educational videos on sex-roles attitudes can be strengthed.

The mechanism of change can be persuasive communication that includes several channels of communication. There are different levels of communication effort processes (engagement level of the audience) where persuasion can bring along attitudinal change.

Practice from schools suggests that the act of watching a video where an instructor/ employer performs a task has been shown to increase the confidence of students in believing they could also perform the same task. The trustworthiness of the presenter is essential, as facilitating changes starts with trust of the change agent.

It is about role models in society and those closer to workplace who introduce modern sex roles. It starts with employer attitude towards employees with families, and understanding of work and life balance both in legal as well as human perspective. Additionally, the employer should be open for honest and meaningful discussions on balancing work and family life with his/ her employees.

The effect of education (educational videos) can be strengthened by combining educational videos with case study analysis and real-life scenario discussions.

Supervisor and colleague support is important for the actual implementation of workplace policies and for managing work and personal life. It is important to note that in many cases, emotional support explains more variance in work-life conflict than work-family benefits.

Research findings and real-life case studies suggest that instrumental support (education, regulations) in the workplace is solely not enough to achieve a successful work-life balance. Instead, we need a supportive working environment, that is a family-friendly organisational culture, diversity, acceptance and inclusion of all employees, as well as individual recognition and approach, complementing the instrumental support efforts.

Limitations. The main limitation of this study is originating mainly from the scope of data analysis. For this research, the author measured the differences between the control and treatment group as well as dissimilarities across genders by using descriptive analysis. Attitudes on traditional and modern sex roles and maternity fit 
for career could be also analysed based on different age groups, educational background, and household types. The analysis methodology can also be expanded to further understand the rationale behind self-reporting of scales of attitudes and whether people behave differently in a socially sensitive environment. All of these areas can be further explored in future studies.

\section{References}

[1] Anja-Kristin Abendroth et Laura den Dulk 2011. "Support for the work-life balance in Europe: the impact of state, workplace and family support on worklife balance satisfaction », Work, employment and society. 2011, vol.25 no 2. p. 234-256.

[2] Bartley Sharon J. , Priscilla W. Blanton \& Jennifer L. Gilliard (2005) Husbands and Wives in Dual-Earner Marriages: Decision-Making, Gender Role Attitudes, Division of Household Labor, and Equity, Marriage \& Family Review, 37:4, 6994, DOI:

[3] Beere, C.A. 1990. Gender roles: A Handbook of Tests and Measures. Greenwood Press: New York.Behr, D., Braun, M., Kaczmirek,

[4] Bandilla, L, W., 2012. Testing the Validity of Gender Ideology Items by Implementing Probing Questions in Web Surveys. Field Methods 0, 1-18.

[5] Budig, M. J., Misra, J., \& Boeckmann, I. (2012). The motherhood penalty in cross-national perspective: The importance of work-family policies and cultural attitudes. Social Politics, 19(2), 163-193.

[6] Bruckmüller, S 1, Branscombe, N 2005 The Glass Cliff: Evidence that Women are Over-Represented in Precarious Leadership Positions, British Journal of Management

[7] Bruckmüller, S 1, Branscombe, N (2015) The glass cliff: when and why women are selected as leaders in crisis contexts. British Journal of Social Psychology

[8] Correll, Shelley J. , Stephen Benard, and In Paik, Getting a Job: Is There a Motherhood Penalty? American Journal of Sociology, Vol. 112, No. 5 (March 2007), pp. 1297-1339. 2007.

[9] Diekman, Amanda B., Wind Goodfriend Rolling with the Changes: A Role Congruity Perspective on Gender Norms November 2006, Psychology of Women Quarterly 30(4):369 - 383

[10] DIRECTIVE (EU) 2019/1158 OF THE EUROPEAN PARLIAMENT AND OF THE COUNCIL of 20 June 2019 on work-life balance for parents and carers and repealing Council Directive 2010/18/EU. https://eur-lex.europa.eu/legalcontent/EN/TXT/PDF/?uri=CELEX:32019L1158\&from=ET

[11] Glass, J. 2004. Blessing or Curse? Work-Family Policies and Mothers' Wage Growth over Time. Work and Occupations 31:367-94.

[12] Eagly, A., Makhijani, M., Klonsky B. 1992. Gender and the Evaluation of Leaders: A Meta- Analysis. The American Psychological Association, Psychological Bulletin article 1992, Vol. III, No. 1, 3-22. 
[13] Eagly, A., Johannesen-Schmidt, M. 2001. The leadership styles of women and men. Journal of The Society for Psychological Study of Social issues, Vol. 57, No. 4, pp. 781-797.

[14] Eagly, A. H., \& Karau, S. J. (2002). Role congruity theory of prejudice toward female leaders. Psychological Review, 109(3), 573-598.

[15] Haar, J. M., Russo, M., Suñe, A., \& Ollier-Malaterre, A. (2014). Outcomes of work-life balance on job satisfaction, life satisfaction and mental health: A study across seven cultures. Journal of Vocational Behavior, 85(3), 361-373.

[16] Jakobsson, N., \& Kotsadam, A. (2010). Do attitudes toward gender equality really differ between Norway and Sweden?. Journal of European Social Policy, 20(2), 142-159.

[17] Kremer, M. 2006. The Politics of Ideals of Care: Danish and Flemish Child Care Policy Compared. Soc. Polit. Int. Stud. Gend. State Soc. 13, 261-285.

[18] Kurowska, A. 2016. (De)familialization and (De)genderization - Competing or Complementary Perspectives in Comparative Policy Analysis? Social Policy \& Administration, 52(1): 29-49.

[19] Lauri, T., Poder, K., Ciccia, R. 2019. Pathways to Gender Balance: A Configurational Analysis of Childcare Instruments and Outcomes in 21 European Countries. Social Policy \& Administration, 54 (5): 646-665.

[20] Ridgeway, Cecilia L. and Shelley J. Correll. 2004. "Unpacking the gender system: A theoretical perspective on cultural beliefs in social relations." Gender \& Society 18(4): 510-531.Porter, N. B., 2006. Re-Defining Superwoman: An Essay on Overcoming the Maternal Wall in the Legal Workplace. 13 Duke Journal of Gender Law \& Policy, 55-83.

[21] Simpson, R., Altman, Y. 2000. The time bounded glass ceiling and young women managers: career progress and career success - evidence from the UK. Article in Journal of European Industrial Training, 190-198, MCB University Press.

[22] TOP 100 Estonian companies database (https://dea.digar.ee/cgibin/dea?a=d\&d=aptopsada20201203.2.9.1)

[23] Walter, J. 2018. Measures of gender role attitudes over time. Doctoral disstertation, Inauguraldissertation zur Erlangung des akademischen Grades einer Doktorin der Sozialwissenschaften, Universität Mannheim.

[24] Williams, J. 2004. Hitting the Maternal Wall. American Association of University Professors, Academe, Vol. 90, No. 6, pp. 16-20.

[25] Williams, J. 2005. The Glass Ceiling and the Maternal Wall in Academia. New directions for higher education, No. 130, pp. 91-105, Wiley Periodicals Inc.

[26] Wheatley, Dan 2012. "Work-life balance, travel-to-work, and the dual career household », Personnel review. 2012, vol.41 no 6. p. 813-831. 